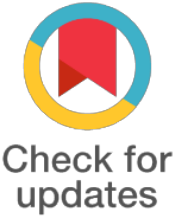

*For correspondence:

chethicamha@yahoo.com

Competing interests: The authors declare that no competing interests exist.

Received: 2017-07-15 Accepted: 2017-08-04 Published: 2017-09-05

Copyright The Author(s) 2017. This article is published with open access by BioMedPress (BMP).

This article is distributed under the terms of the Creative Commons Attribution License (CC-BY 4.0) which permits any use, distribution, and reproduction in any medium, provided the original author(s) and the source are credited.

\author{
Ha Che Cam, Le Duy Minh, Le Minh Tri, Pham Thi Ngoc Phuong, Tran Huu \\ Phuc
}

\section{An investigation on the deleterious effects of cryoablation on hepatocellular carcinoma}

Hue College of Sciences, Hue Industrial College and Hue Central Hospital, Thua Thien Hue, VietNam

\begin{abstract}
Vietnam is witnessing an elevated mortality rate of hepatocellular carcinoma (HCC) [1]. The early symptoms of this cancer are usually vague and not unique to liver disorders, thus presenting difficulties in diagnosis and treatment. Therapies like chemo- and radiotherapy can only prolong patients' lives without possible cure [2]. At present, in addition to novel therapies, cryoablation has demonstrated its therapeutic effectiveness in certain countries [3-6]. However, this technique is still uncommon in Vietnam. With the aim of introducing cryoablation to HCC treatment, we have developed a piece of cryoprobe apparatus and investigated its deleterious effects at tissue levels and in vitro cell viability. Our results showed that the cryoprobe using liquid nitrogen reached $-159.90 \mathrm{C}$ within 15.4 seconds. While full deleterious effects were witnessed in mice within investigated freezing duration, the same effects were only seen in rabbits after 90 seconds of freezing. 60 and 45 seconds of freezing only caused cellular damage. Finally, human malignant cells were killed by two freeze thaw cycles in 90 seconds and 9 minutes respectively
\end{abstract}

\section{Keywords}

Human malignant cells, hepatocellular carcinoma, cryoablation

Funding

\section{References}

1. Ferlay, J., et al. GLOBOCAN 2012 v1.o, Cancer Incidence and Mortality Worldwide: IARC CancerBase No. 11 [Internet]. (International Agency for Research on Cancer, Lyon, France, 2013). 2. Longe, J.L. Liver Cancer. in The Gale encyclopedia of cancer: A guide to cancer and its treatments 2nd ed, Vol. 2 673-678 (Thompson Gale, 2005). 3. Shimizu, T., et al. Outcome of MR-guided percutaneous cryoablation for hepatocellular carcinoma. J Hepatobiliary Pancreat Surg 16, 816-823 (2009). 4. Rong, G., et al. Long-term outcomes of percutaneous cryoablation for patients with hepatocellular carcinoma within Milan criteria. PLos ONE 10, e0123065 (2015). 5. Wu, B., et al. Magnetic resonance imaging-guided percutaneous cryoablation of hepatocellular carcinoma in special regions. Hepatobiliary Pancreat Did Int 9, 384-392 (2010). 6. Orlacchio, A., et al. 